Original Article Received/Accepted Dates

05.11.2021/21.12.2021

DOI: 10.52096/jsrbs.7.14.16
Sosyal Araştırmalar ve Davranış Bilimleri Dergisi

ISSN:2149-178X

Volume: 7 Issue: 14 Year: 2021

\title{
İç Anadolu Bölgesine Yönelik Sağlık Turizmi Alanında 2006-2020 Yılları Arası Yapılmış Tezlerin İçerik Analizi
}

Dr. Öğr. Üyesi Zişan KORKMAZ ÖZCAN

Süleyman Demirel Üniversitesi İktisadi ve İdari Bilimler Fakültesi

ORCID: 0000-0002-5842-8638 zisankorkmaz@sdu.edu.tr

\section{Harun ÇAKIR}

Süleyman Demirel üniversitesi İktisadi ve İdari Bilimler Fakültesi

Turizm İşletmeciliği

ORCID: 0000-0002-0713-9406

harun.cakir2686@gmail.com

\section{Özet}

İnsanların sağlığı için başka bir bölge veya ülkeye gitmeyi tercih ettiği sağlık turizmi alanında özellikle son zamanlarda çok sayıda çalışma yapılmaktadır. Bu çalışma, İç Anadolu Bölgesine yönelik sağlık turizmi alanında yazılmış 2006-2020 yıllarına ait lisansüstü ve doktora tezlerinin incelenmesi amacıyla hazırlanmıştır. $\mathrm{Bu}$ amaç doğrultusunda yayınlanmış olan tezler; türüne, yılına, yayın dillerine, üniversitelere, anabilim dallarına ve enstitülere göre içerik analizi yapılarak sınıflandırılmıştır. Ayrıca, temel konu alanları belirlenmiş ve baz alınan örnekleme yönelik bilgiler verilmiştir. Yüksek Öğretim Kurulu (YÖK) tez veri tabanından "Sağlık Turizmi”, "Termal Turizm”, "Medikal Turizm”, "Engeli Turizmi” ve "Yaşlı Turizmi," anahtar kelimeleri kullanılarak tarama yapılmıştır. Araştırma sonucunda 24 yüksek lisans, 2 doktora tezi olmak üzere toplam 26 adet teze ulaşılmıştır. Yapılan tezlerin \%92,3'ünün yüksek lisans tezi olduğu, \%7,7'sinin doktora tezi olduğu tespit edilmiştir. Yazıldıkları dil bakımından ele alınan tezlerin $25(\% 96,15)$ tanesinin Türkçe, $1(\% 3,85)$ 'inin İngilizce yazıldığı görülmüştür. En çok çalışmayı Konya Selçuk Üniversitesinin yaptığı sonucuna ulaşılmış, yayınlanan tezlerin çoğunluğunun ise 
termal turizm alanında gerçekleştirilmiş olduğu, genellikle müşteri memnuniyeti ve hizmet kalitesi bakımından konuların ele alındığ 1 görülmüştür. Çalışmalarda çoğunlukla anket veri toplama aracının kullanıldığı ve çalışılan örneklem grubunun genellikle sağlık tüketicilerinden oluştuğu tespit edilmiştir. Yapılan bu çalışmanın sağlık turizmi alanında çalışma yapacak olan öğrenci ve akademisyenlere yardımcı olacağ1 düşünülmektedir.

Anahtar Kelimeler: Sağlık Turizmi, İç Anadolu Bölgesi, İçerik Analizi, Yüksek Lisans Tezleri, Doktora Tezleri

\title{
Content Analysis Of Thesis Made Between 2006-2020 in The Field Of Health Tourism to the Central Anatolia Region
}

\begin{abstract}
In the field of health tourism, where people prefer to go to another region or country for their health, there have been many studies recently. This study was prepared for the purpose of examining the graduate and doctoral theses of the years 2006-2020 written in the field of health tourism for the Central Anatolia region. Theses published for this purpose; It was classified by content analysis according to type, year, publication languages, universities, departments and institutes. In addition, basic subject areas were determined and information about the sample based on was given. The thesis database of the Council of Higher Education (YÖK) was searched using the keywords "Health Tourism", "Thermal Tourism", "Medical Tourism", "Tourism for the Disabled" and "Tourism for the Elderly". As a result of the research, a total of 26 theses, including 24 master's and 2 doctoral theses, were reached. It was determined that $92.3 \%$ of the theses were master's thesis and 7.7\% were doctoral thesis. It was seen that $25(96.15 \%)$ of the theses, which were handled in terms of the language in which they were written, were written in Turkish and $1(3.85 \%)$ were written in English. It was concluded that Konya Selcuk University did the most work, and it was seen that most of the published theses were carried out in the field of thermal tourism, and the subjects were generally discussed in terms of customer satisfaction and service quality. It was determined that the survey data collection tool was mostly used in the studies and the sample group studied was generally composed of health consumers. It is thought that this study will help students and academicians who will work in the field of health tourism.
\end{abstract}

Key words: Health tourism, Central Anatolia Region, Content Analysis, Master Theses, Doctoral Theses. 


\section{Giriş}

Kişilerin sağlık hizmetlerinden yararlanmak maksadı ile bir başka ülkeye yapmış oldukları uluslararası seyahatler sağlık turizminin tanımını ortaya koymaktadır. Aynı zamanda sağlık hizmetini sunanların sağlık hizmetleri vermek amaçlı yapmış oldukları seyahatler de sağlık turizminin içine girmektedir (Karakoç, 2017). Ayrıca sağlık turizmi; medikal turizm, termal ve spa-wellness turizmi, engelli ve ileri yaş turizmini içine almaktadır (Aydın, 2012: 93)

Yapılan bu çalışmada, zamanla popülerlik kazanmış olan sağlık turizmine, Türkiye'nin İç Anadolu Bölgesi açısından bakarak sağlık turizmi alanında yapılmış lisansüstü tezlerin ele alınarak incelenmesiyle genel bir bakış amaçlanmıştır. Bu amaçtan yola çıkarak bilimsel açıdan büyük öneme sahip olan lisansüstü tezlerin içeriklerinin değerlendirilmesi yapılmıştır. Bu çalışmanın içeriğinde de içerik analizi koşul ve kuralları yer almaktadır. İçerik analizi yöntemi, istatistiksel verilerin kullanımıyla elde edilmiş olan verilerin üzerinden yorumlama yapma imkânı sağlamaktadır. İstatistiksel verilerin kullanılması, araştırmacının yorumunu objektif ve sistematik bir biçimde yapabilmesini sağlamaktadır (Koçak ve Arun, 2006, 24). Zira bu çalışama, sağlık turizmi açısından İç Anadolu Bölgesindeki gelişimleri ve eğilimleri ortaya koymak, eksikliklerin tespit etmek için yapılmıştır. Bu sayede ileride sağlık turizmi alanında akademik çalışma yapacak olan araştırmacılara çalışma konusu belirlemelerinde yardımcı olacağı düşünülmektedir. 


\section{Sağlık Turizmi}

Sağlık Turizmi; "insanların, sağlıklarını korumak ve iyileşmek amaçlı belirli bir süreliğine (genellikle 21 gün) yer değişikliği yaparak, doğal kaynaklarla gerçekleştirilen turistik tesislere giderek konaklama, beslenme, kür uygulaması ve eğlence gereksinimlerini karşılaması sonucunda gerçekleştirmiş oldukları seyahatlerdir" (Boz, 2004: 132). Sağlık turizmi, kişilerin tedavi olmak amaçlı yurtdışına yapmış oldukları hareketliliği şeklinde de tanımlanmıştır. (Tengilimoğlu ve Yalçın Balçık, 2009). Diğer bir tanım da sağlık turizmi sağlığın güçlendirilmesi, sağlığın idame ettirilmesi amacıyla ortaya çıkan ve tatili de kapsayan konaklamalar, seyahatler ve organizasyonlardan meydana gelen olay ve ilişkilerin tümü olarak tanımlanmaktadır (Gençay, 2007). Kültür ve Turizm Bakanlığı'na göre sağlık turizmi; “tedavi amaçlı gerçekleştirilen seyahatler olarak tanımlanmaktadır. Diğer bir ifadeyle, sağlık turizmi, fizik tedavisine ve rehabilitasyona ihtiyaç duyan kişilerin, uluslararası hasta potansiyelini kullanarak sağlık kuruluşlarının büyümesine olanak sağlayan turizm türüdür” (KTB,2020).

Kişilerin ikamet etmiş oldukları yerden, tatil amacıyla farklı bir destinasyona gitmiş olmaları, seyahat esnasında plansız ve acil bir şekilde sağlık hizmeti almak durumunda kalmaları "Turistin Sağlığı” olarak ifade edilmektedir (İçöz, 2009). "Turizm Sağlığı”, turistin konaklama yaptığı, gezmiş oldukları çevrenin sağlıklı koşullara sahip olması ve çevrenin turiste, turistin çevreye, sağlık yönünden etkisini kapsamaktadır (Aydın ve Şeker, 2011).

Turist sağlığı ve sağlık turizmi, anlam olarak farklı olsalar da birbiri ile karıştırılan kavramlardır. Türkiye Sağlık Bakanlığı'nın raporunda yer alan ve sağlık turizmi kavramına yönelik amaçlarla hizmet satın alan ve seyahatte bulunan kişilere "sağlık turisti" denilmektedir. (Kaya, Özer, Karsavuran ve Yıldırım, 2013). Türkiye, yaz turizminden elde ettiği kazancının yanında önem verilmesi halinde belki de daha fazla gelir elde edeceği sağlık turizmi destinasyonlarına sahiptir. Bir turizm çeşidi olan sağlık turizmi kaplıcalar, medikal tedaviler, termal, spa-wellnes ve şifalı çamurlar gibi tüm sezon turist çekebilecek faaliyetleri kapsamaktadır. Sağlık turizmi; medikal turizm, termal ve spa - wellness turizm, engelli ve ileri yaş turizmini içine almaktadır (Aydın, 2012) 


\subsection{Medikal Turizm}

Medikal turizm, turistlerin, tedavi amaçlı ve rehabilite edici sağlık hizmetlerinden yararlanmak maksadıyla ülke sınırları dışına yapmış oldukları seyahatler şeklinde tanımlanmaktadır (Pollard, 2010). Yapılan farklı tanıma göre ise medikal turizm, "kişiyi daha sağlıklı yapan seyahat türü" olarak tanımlanmıştır (Erfurt-Cooper ve Cooper, 2009: 4- 5). Literatürde yer alan bazı çalışmalar sağlık nedenlerinden dolayı gerçekleştirilen bütün seyahatleri medikal turizm ve sağlık turizm ile aynı anlama gelecek şekilde kullanılmış olsa da aktif sağlık hizmetlerinden faydalanmak amaçlı gerçekleştirilen ulusal ve uluslararası seyahat hareketlilikleri "Medikal Turizm” hareketi olarak değerlendirilmektedir (Reisman, 2010). Bahsedilmiş olan sağlık hizmetleri geniş kapsamda değerlendirilebileceği gibi, daha çok estetik cerrahi, diş hastalıkları, kalp-damar cerrahisi, obezite ve tüp bebek uygulamalarını da kapsadığı görülmektedir (Horowitz ve Rosensweig, 2007).

Medikal turizm hareketinde, düşük maliyet, kullanılan tıp teknolojisi ve gidilecek destinasyonun turistik alt yapısı talebi etkileyen en önemli unsurlardır. Amerika'da gerçekleşen bir by-pass ameliyatının maliyeti 113.000 dolar civarında iken, Hindistan'da 10.000, Malezya'da 9000, Polonya'da 7.140 dolar civarındadır (Lunth vd., 2011). Ayrıca yapılacak operasyon ve maliyeti dışında, gidilecek ülkenin sunmuş olduğu tatil seçenekleri de talebi etkileyen bir başka unsurdur. Yapılan araştırmalarda medikal turizm alanında lider konumda olan ülkeler sırasıyla Hindistan, Tayland, Singapur, Amerika Birleşik Devletleri ve Malezya olarak belirtilmektedir. Fakat Hindistan medikal turizmin merkezi olarak kabul edilmemektedir. Hindistan'da tedavi maliyetlerinin düşük olması ve yüksek enfeksiyon riski taşıyan ameliyatlarda sağlamış olduğu başarı ile dünya genelinde akredite olmuş en iyi hastaneleriyle karşılaştırılabilir duruma gelmiştir (Connel, 2006; Bookman ve Bookman, 2007). Singapur ise medikal turizm açısından talep gören bir ülke olmasına rağmen, maliyetleri açısından en yüksek olan destinasyondur (Connell, 2013).

Türkiye'de sağlık turizmi denildiğinde, önceden akla gelen ilk şey şifalı su kaynakların olduğu yerde kurulmuş olan oteller ve termal tedavilerin uygulandığı sağlık kuruluşları gelmekteydi. Ancak son yıllarda, başta özel sektörler olmak üzere ciddi gelişmeler gösterilmiş ve sağlık turizminde önemli konumda olan ülkelerle yarışır duruma gelinmiştir. Son zamanlarda özel sağlık kurulularındaki gelişmeler kamu hastanelerinin bu yöndeki eksikliklerini gidermesiyle birlikte sağlık turizmi alanında yükselen bir değer haline gelmiştir (Özgül, 2014:23). Son dönemlerde 
Türkiye'yi çeşitli ülkelerde çok sayıda insanın tedavi amaçlı tercih ettiği görülmektedir. Sağlık turistlerinin tercih etmelerindeki en temel neden ise çağdaş yöntemlerle gerçekleştirilmiş olan tıbbı operasyonların diğer ülkelere göre daha uygun fiyatlarla yapılmış olmasıdır. Plastik ve estetik operasyonları, kalp ameliyatı, tüp bebek, göz ameliyatı, kanser tedavileri, beyin cerrahisi, ortopedi, diş gibi çoğu dalda yabancı hastalar düşük maliyet, yüksek kalite ve teknoloji standartları nedeni ile Türkiye'nin sağlık kuruluşlarını terci etmektedirler (İçöz, 2009).

\subsection{Termal ve Spa - Wellness Turizmi}

İnsanlık tarihinde sıcak su kaynakları önemli bir yere sahiptir. İlkçağlardan beri insanların yerleşim yerlerini belirlemede termal su kaynakları, önemli kriteri olmuştur. Ayrıca bu termal su kaynaklardan kullanma suyu, içme suyu ve şifa amaçlı çeşitli şekillerde faydalanılmıştır (Öztürk ve Bayat, 2011). Termal turizm, doğal yollarla belirli bir sıcaklıkta yer yüzeyine çıkan ve yararlı mineralleri içerisinde barındıran şifalı suların, çamurların ve buhar kaynaklarının bulunduğu yerlerde, bölgeye özgü iklim koşulları içerisinde gerçekleştirilen turizm çeşididir (İlban vd., 2008). Kaplıca veya Termal turizm; içme, termal su banyosu, çamur banyosu gibi yöntemlerin dişında, iklim kürü, fizik tedavi, egzersiz, rehabilitasyon, diyet, psikoterapi, gibi destek tedavilerini de içine alan bir turizm hareketi şeklinde de tanımlanmaktadır (Akat, 2000).

"SPA" Latince "Salus Per Aquam" sözcüklerinin baş harflerinden gelmiş olup "su ile gelen iyilik" veya "su ile gelen sağlık" anlamlarını taşımaktadır (Türksoy ve Türksoy, 2010). SPA'nın kavramsal anlamı ülkeler bazında karşılaştırıldığında değişiklik göstermektedir. Örneğin; SPA bazı bölgelerde, çamur ve suyu kullanarak özel bir bakım yöntemi sağlamak anlamındayken; farklı bölgelerde ruh, akıl ve vücut arasındaki ilişki ile ilgili olarak değerlendirilmekte, ruhsal olarak yenilenme ve enerji kazanımı anlamlarına gelmektedir. Bir başka ifadeyle; turizm başlığı kapsamında sakin ve huzurlu, ruh dinlendirici bir tatil anlamına gelmektedir (Hasanov, 2018).

Wellness terimi ve felsefesi 1959 senesinde Amerikan Doktor Halbert Luis Dunn'ın çalışmaları sayesinde gelişmiş̧ir. Wellnes felsefesi ruh, zihin ve beden sağlığının dengede tutulması ve artırılmasına yönelik bir yaşam tarzı olarak betimlenmiştir. Temeli Amerika Birleşik Devletleri'ne dayanan bu terim, bütünsel, sürekli gelişim gösteren ve değişim sağlayan bir sağlı anlayışını ifade 
etmektedir (Güleç, 2011). Wellness deneyimi elde etmek isteyen kişiler, genellikle sağlıklı bireyler olup, sağlıklarının devamını korumak amaçlı farklı sağlık uygulamalarından yararlanmak isteyen kişilerdir (Asadi ve Daryaei, 2011). Ayrıca Termal ve Spa-Wellness turizm uygulamalarında hastalık sonrasındaki rehabilite dönemleri veya kalıcı hasara maruz bırakan rahatsızlıklarda hasarın kısmi olarak iyileştirilmesine yönelik termal- spa merkezlerinde bulunan sağlık personelleri ve diğer yetkili personelce yapılan tedaviye destek olacak veya rehabilite sağlayacak uygulamalar bulunmaktadır (Özer ve Sonğur, 2012).

Türkiye'de ve Dünya'da, Wellness ve SPA hizmetleri yaygın kullanıma sahip sağlık turizmi hizmetleri arasındadır. Uluslararası standartlarda otel işletmelerine bakıldığında dikkatleri çeken sağlık turizmi hizmetleri, yüksek kalite donanım sahibi olup, turistlerin ilgisini çekerek rekabet piyasası oluşturmaktadır. Wellness kapsamındaki turistler sağlıklarını korumak, geliştirmek ve iyileştirmek adına sağlanan faaliyetleri gerçekleştirmek isteyen kişilerdir. Bu bağlamda, Wellness kavramı çok boyuta sahip bir olgu şeklinde düşünülüp yalnızca fiziksel olarak zindelik hali değil, psikolojik ve zihinsel anlamda da iyi olma hali olarak tanımlanmaktadır. Wellness turizminde bir hastalı̆̆ın tedavi safhasından da önce, bu hastalık daha meydana gelmeden engellenebileceği öngörülmektedir (Deniz, 2016).

\subsection{Engelli ve İleri Yaş Turizmi}

Engelli ve yaşlı turistlerin rehabilitasyon ve bakımlarının yapılması amacıyla geriatrik tedavi merkezleri, klinik konukevleri veya bakım evlerinde, alanında eğitimli ve sertifika sahibi olan personeller tarafindan gerçekleştirilen uygulamaların tamamı engelli ve ileri yaş turizmini oluşturmaktadır (Özer ve Sonğur, 2012). Bakıma ihtiyacı olan yaşlıların, bakım hizmetlerinden yararlanmak amaçlı farklı ülkelere seyahat etmeleri, ileri yaş turizmi şeklinde ifade edilmektedir (Özsarı ve Karatana, 2013).

Türkiye'nin ve diğer ülkelerin nüfuslarına göre engelli oranları incelendiğinde yüksek oranda engelli nüfusun olduğu görülmektedir. Bu nedenle engelli kişilerin diğer insanlar gibi seyahat etmeleri, gezmeleri, eğlenmeleri ve tedavi olma ihtiyaçları göz ardı edilemeyecektir. Engelli 
nüfusun yüksek olması ülkemizde ve dünyanın diğer ülkelerinde sağlık turizminin yüksek oranda potansiyele sahip olduğunu göstermektedir (Aydın ve Yılmaz, 2010).

\section{Yöntem}

\subsection{Araştırmanın Amacı ve Kapsamı}

Yapılan bu çalışmanın amacı, İç Anadolu Bölgesine yönelik sağlık turizmi alanında yapılmış olan yüksek lisans ve doktora tezlerinin incelenmesidir. Bu amaç doğrultusunda, sağlık turizmi alanında yapılmış olan tez çalışmaları incelenerek, genel anlamda bir sonuca ulaşmak için içerik analizi yöntemi için gerekli olan veriler, doküman incelemesi yoluyla elde edilmiştir.

Çalışma kapsamında; yayınlanan tezlerin türü, yayınlandıkları dil, yapıldıkları üniversiteler, enstitüler ve anabilim dalları gibi özellikler yanında, yayınlandıkları yıllara göre dağılımlarını ortaya koymak, çalışılan temel konu alanlarını ve araştırmaların yapıldığı örneklem gruplarını oluşturmak yer almaktadır. Ayrıca hangi şehirler üzerine çalışıldığını, en sık çalışılan ilişkili olduğu konuları ve alt konu alanlarını belirlemek amaçlanmıştır.

Yüksek Öğretim Kurumu (YÖK) tez veri tabanından "sağlık turizmi, medikal turizm, termal turizm, engelli turizmi yaşlı turizmi ve ileri yaş turizmi” anahtar kelimeleri kullanılarak tarama yapılmıştır. Yapılan tarama sonucu yayınlanmış 24 tane yükssek lisans tezi 2 tane doktora tezi olmak üzere toplam 26 tane teze ulaşılıp araştırma kapsamında incelenmiştir.

\subsection{Araştırma Problemi Tanımlama}

Bu çalışmanın içeriğinde de içerik analizi koşul ve kuralları yer almaktadır. İçerik çözümleme, araştırılacak içeriğin nesnelliği, ölçülebilir olması ve doğrulanabilir olmasıyla anlam kazanmaktadır. Yapılan araştırmada mühim olan, araştıranın incelemeyi istediği konu hakkındaki ölçütlerin net olmasıdır. Ayrıca ölçütlerin istatistiksel bağlamda çözümleme yöntemi bakımından geçerli olması da önem teşkil etmektedir (Fiske, 2014, 248). İçerik analizi yöntemi, istatistiksel verilerin kullanımıyla elde edilmiş olan verilerin üzerinden yorumlama yapma imkânı 
sağlamaktadır. İstatistiksel verilerin kullanılması, araştırmacının yorumunu objektif ve sistematik bir biçimde yapabilmesini sağlamaktadır (Koçak ve Arun, 2006, 24). İçerik analizi yöntemi, niceliksel veriye ulaşım sağlamayı hedef haline getirmiş yöntemdir. $\mathrm{Bu}$ yöntem için belirli safhaların izlenmesi gerekmektedir.

İçerik değerlendirmesinin ilk adımı araştırma sorularını belirlemektir. Amaçsız yapılan çalışmaların önüne geçebilmek için bu sorular önem taşımaktadır. Bu nedenle yapılacak analizin amacı açık bir şekilde belirtilmeli ve literatür taraması ile araştırma problemlerinin belirlenmesi kolaylaştırılarak, araştırma soruları oluşturulmalıdır (Balcı ve Bekiroğlu, 2012). Araştırmacı, yapmış olduğu çalışmalarda nelerin araştırma konusu olduğuna ve hangi soruların daha anlamlı ve ilgi çekici olduğuna kendisi karar vermektedir. Araştırmaların nesnelliği açısından araştırmacı, varsayımlarını dayandırmış olduğu kuramsal düşünceleri açık bir şekilde dile getirmelidir (Gökçe, 2006). Yapılan çalışmanın soruları aşağıda belirtilmiştir:

1. Yapılan tez çalışmaları türü ne orandadır?

2. Sağlık turizmi hangi anabilim dallarında ele alınmıştır?

3. Tezlerin yayınladığı yıl aralığı nedir?

4. Yayınlanan tezin dili nedir?

5. Yazılan tezler hangi üniversitelerde yayınlanmıştır?

6. Tezlerin Yayınladığı Enstitüler nelerdir?

7. Tezlerin temel konu alanlarına göre dağılımı nedir?

8. Tezlerin üzerinde durduğu konular nedir?

9. Tezlerin İç Anadolu Bölgesinde Yer Alan Şehir Örneklemlerine Göre Dağılımı nedir?

10. Tezlerin örneklem grubu dağılımları nelerdir?

11. tezlerde kullanılan veri toplama teknikleri nelerdir 


\section{3. Örneklemin Belirlenmesi}

İçerik analizinde, sosyal bilim alanlarında örneklemi oluştururken en önemli koşul, örneklemin, araştırma evrenini bütününü temsil etmesidir. Örneklem, araştırmacının evrene ait olan verileri, evreni temsil edecek olan küçük birimler şeklinde incelemesini sağlamaktadır. Geniş bir alana sahip olan bir araştırmada evreni temsil edecek biçimde sınırlandırmak kaçınılmazdır. İçerik değerlendirme yönteminde evren dört biçimde sınırlandırılabilir; nerede, ne zaman, hangi aracıyla ve hangi konuda (Koçak ve Arun, 2006).

Yapılan bu araştırmanın örneklemini, Sağlık turizmi alanında İç Anadolu Bölgesine yönelik Yüksek Öğretim Kurumu'nda (YÖK) yer alan ve 2006-2020 yılları arasında yayınlanmış yüksek lisans ve doktora tezleri oluşturmaktadır. Bu çalışmanın sınırlılığını oluşturan nedenler ise ulaşım sağlanmak istenen tezlerin erişimine izin verilmemesi veya yüklenme hatası gibi sebeplerdir. $\mathrm{Bu}$ sınırlılıklardan dolayı, toplamda 24 yüksek lisans ve 2 doktora tezine ulaşım sağlanmıştır.

\section{Bulgular}

Araştırma kapsamındaki sağlık turizmi alanında yayınlanan tezlerin türü, dili, yapıldıkları üniversite, enstitü ve anabilim dallarını içeren özellikler aşağıdaki tablolarda gösterilmiştir.

\section{Tablo 1: Sağlık Turizmi Alanında Yayınlanan Tezlerin Türü}

TEZ TÜR $\ddot{U}$

YÜKSEK LISANS

DOKTORA

TOPLAM
Frequency

24

2

26
Percent

$\% 92,3$

$\% 7,7$

$\% 100$

Tablo 1'de Sağlık turizmi alanında İç Anadolu Bölgesine yönelik yapılmış tez çalışmaları ele alındığında, Yüksek Öğretim Kurumu'na ait web sitesinde bulunan toplamda 26 tane izinli teze ulaşım sağlanmıştır. Bunların 24 tanesini yüksek lisans tezleri oluşturmuş olup toplam tezler içerisindeki oranı \%92,3 tür. Ulaşım sağlanan tezlerin 2 tanesini doktora tezleri oluşturmakta olup toplam tezler içerisindeki oranının \%7,7 olduğu görülmektedir. 
Tablo 2: Sağlık Turizmi Alanında Yayınlanan Tezlerin Yapıldığı Ana Bilim Dalı

\begin{tabular}{|c|c|c|c|c|}
\hline \multirow{2}{*}{$\begin{array}{c}\text { Anabilim dalları } \\
\text { Sağlık kuruluşları yöneticiliği }\end{array}$} & \multicolumn{2}{|c|}{ Yüksek lisans tezi } & \multicolumn{2}{|c|}{ Doktora tezi } \\
\hline & 1 & $\% 4,17$ & - & \\
\hline Turizm işletmeciliği & 6 & $\% 25,00$ & - & \\
\hline Turizm işletmeciliği eğitimi & 1 & $\% 4,17$ & - & \\
\hline İşletme & 5 & $\% 20,83$ & 2 & $\% 100$ \\
\hline Sağlık yönetimi & 2 & $\% 8,33$ & - & \\
\hline İşletme yönetimi & 1 & $\% 4,17$ & - & \\
\hline Şehir ve bölge planlama & 1 & $\% 4,17$ & - & \\
\hline İktisat & 1 & $\% 4,17$ & - & \\
\hline Jeoloji mühendisliği & 1 & $\% 4,17$ & - & \\
\hline Beden eğitimi ve spor bilimleri & 1 & $\% 4,17$ & - & \\
\hline Coğrafya & 1 & $\% 4,17$ & - & \\
\hline Turizm ve otel işletmeciliği & 2 & $\% 8,33$ & - & \\
\hline Orta öğretim sosyal alanlar & 1 & $\% 4,17$ & - & \\
\hline Toplam & 24 & $\% 100$ & 2 & $\% 100$ \\
\hline
\end{tabular}

Tablo 2'de sağlık turizmi alanında yapılan tezlerin hangi ana bilim dallarında yapılmış olduğu ele alınmıştır. Elde edilen verilere göre İç Anadolu Bölgesine yönelik yüksek lisans tezlerinde en çok turizm işletmeciliği ve işletme anabilim dallarında tez çalışmaları yapıldığı görülmüştür. Turizm işletmeciliği anabilim dalları arasında 6 çalışma \%25 ile en fazla orana sahiptir. İşletme anabilim dalında yapılan 5 tez çalışması yüksek lisans tezleri arasında \%20,83' lük orana sahiptir. Sağlık yönetimi anabilim dalı ile turizm ve otel işletmeciliği anabilim dalında ikişer çalışma bulunup, \%8,33 orana sahiptirler. Sağlık turizmi alanında yüksek lisans tezlerinde en az 1'er tez çalışması bulunan ve \%4,17 oranlarıyla Sağlık kuruluşları yöneticiliği, Turizm işletmeciliği eğitimi, İşletme yönetimi, Şehir ve bölge planlama, İktisat, Jeoloji mühendisliği, Beden eğitimi ve spor bilimleri, Coğrafya ve Orta öğretim sosyal alanlar anabilim dalları olduğu görülmektedir. Doktora tezlerinde ise İç Anadolu Bölgesine yönelik sağlık turizmi alanında yapılmış olan 2 çalışma bulunmaktadır. 
Yapılan doktora tezleri sadece işletme anabilim dalında yapılmıştır. Tezlerin geneline bakıldığında yapılan çalışmaların daha çok turizm işletmeciliği ve işletme anabilim dallarında olduğu görülmektedir. Tabloyu incelediğimizde İç Anadolu Bölgesinde sağlık turizmi alanında doktora tezi olarak sayısının çok az olduğu görülmektedir.

Tablo 3: Sağlık Turizmi Alanında Yayınlanan Tezlerin Yayınlandıkları Yı Aralığı

\begin{tabular}{|l|c|c|c|c|}
\hline & \multicolumn{2}{c|}{ Yüksek lisans tezi } & \multicolumn{2}{c|}{ Doktora tezi } \\
\hline $2006-2010$ & 5 & $\% 21$ & - & - \\
\hline $2011-2015$ & 8 & $\% 33$ & - & - \\
\hline $2016-2020$ & 11 & $\% 46$ & 2 & $\% 100$ \\
\hline Toplam & 24 & $\% 100$ & 2 & $\% 100$ \\
\hline
\end{tabular}

Tablo 3'de Yapılan tezlerin yayınlandıkları yıl aralığına bakılmıştır. Tablo 'da 3 ayrı yıl aralığı belirlenmiştir. 2006 ve 2020 yıl aralığında toplam da 26 tane teze ulaşım sağlanmıştır. Bu tezlerin 24 tanesi yüksek lisans tezi olup, toplam tezler içerisinde \%92,3 orana sahiptir. Doktora tezleri ise 2 tane olup, toplam tezler içerisinde \% 7,7 orana sahiptir. 2006- 2010 yılları arasında 5 (\%21) tane yüksek lisans tezi yayınlanmıştır. 2011-2015 yılları arasında 8 (\%33) tane yüksek lisans tezi yayınlanmıştır. 2016 ve 2020 yılları arasında $11(\% 46)$ tane yüksek lisans ve 2 tane doktora tezi yayınlanmıştır. 2016-2020 yılları arasında ise yüksek lisans tezlerinin arttığını ve bu yıl arasında artık doktora tezlerinin de yazıldığı görülmektedir. Bu sonuç İç Anadolu Bölgesinin sağlık turizmi alanında son 5 yıl içerisinde daha çok ele alındığını göstermektedir.

Tablo 4: Sağlık Turizmi Alanında Yayınlanan Tezlerin Dili

\begin{tabular}{l|c|c|c|c|}
\hline \multicolumn{1}{|c|}{ Dil } & \multicolumn{2}{c}{ Yüksek lisans tezi } & \multicolumn{2}{c}{ Doktora tezi } \\
\hline Türkçe & 23 & $\% 96$ & 2 & $\% 100$ \\
\hline Ingilizce & 1 & $\% 4$ & - & - \\
\hline Toplam & 24 & $\% 100$ & 2 & $\% 100$ \\
\hline \hline
\end{tabular}


Tablo 4'te sağlık turizmi alanında İç Anadolu Bölgesine yönelik yapılan tezlerin yayınlandığı diller incelenmiştir. Yapılan araştırma neticesinde elde edilen verilere göre yapılan, yüksek lisans tezlerinin 23 adetinin, doktora tezlerinin 2 adetinin Türkçe dilinde yazıldığı görülmektedir. Yüksek lisans tezlerinden sadece 1 tanesi İngilizce olarak yazılmıştır. Doktora tezlerinde ise İç Anadolu Bölgesine yönelik sağlık turizmi alanında İngilizce olarak çalışma yapılmamıştır.

Tablo 5: Sağlık Turizmi Alanında Yayınlanan Tezlerin Yayınlandığı Üniversiteler

\begin{tabular}{|l|c|c|c|c|}
\hline \multicolumn{1}{|c|}{ Üniversiteler } & \multicolumn{2}{c}{ Yüksek lisans tezi } & \multicolumn{2}{c|}{ Doktora tezi } \\
\hline Cumhuriyet Üniversitesi & 2 & $\% 8,3$ & - & - \\
\hline Selçuk Üniversitesi & 5 & $\% 21,8$ & - & - \\
\hline İstanbul Gelişim Üni. & 1 & $\% 4,1$ & - & - \\
\hline Atılım Üniversitesi & 2 & $\% 8,3$ & - & - \\
\hline Beykent Üniversitesi & 1 & $\% 4,1$ & - & - \\
\hline Niğde Üniversitesi & 2 & $\% 8,3$ & - & - \\
\hline Gazi Üniversitesi & 1 & $\% 4,1$ & 1 & $\% 50$ \\
\hline Ankara Yıldırım Beyazıt Üniversitesi & - & - & 1 & $\% 50$ \\
\hline Kayseri Üniversitesi & 1 & $\% 4,1$ & - & - \\
\hline Orta Doğu Teknik Üniversitesi & 1 & $\% 4,1$ & - & - \\
\hline Eskişehir Osmangazi Üniversitesi & 1 & $\% 4,1$ & - & - \\
\hline Karabük Üniversitesi & 1 & $\% 4,1$ & - & - \\
\hline Aksaray Üniversitesi & 1 & $\% 4,1$ & - & - \\
\hline Erciyes Üniversitesi & 1 & $\% 4,1$ & - & - \\
\hline Afyon Kocatepe Üniversitesi & 1 & $\% 4,1$ & - & - \\
\hline Düzce Üniversitesi & 1 & $\% 4,1$ & - \\
\hline Abant İzzet Baysal Üniversitesi & 1 & - & - \\
\hline Necmettin Erbakan Üniversitesi & 1 & & - \\
\hline Toplam & 1 & $\% 00$ & - \\
\hline
\end{tabular}


Sağlık turizmi alanında yüksek lisans tezlerinde en fazla tez çalışmasının bulunduğu üniversite, 5 tez çalışması ve \%21,8'lik oranla Selçuk Üniversitesi olduğu görülmektedir. İç Anadolu Bölgesinde sağlık turizmi alanına yönelik yapılan yüksek lisans çalışmalarının en az olduğu üniversiteler ise, 1'er tez çalışması ve \%4'lük oranla, İstanbul Gelişim, Beykent, Gazi, ODTÜ Kayseri, Eskişehir Osman Gazi, Karabük, Aksaray, Erciyes, Afyon Kocatepe, Düzce, Abant İzzet Baysal ve Necmettin Erbakan Üniversiteleri olduğu görülmektedir Doktora tezlerinde ise sadece İç Anadolu Bölgesine yönelik sağlık turizmi alanında, Gazi ve Ankara Yıldırım Beyazıt üniversitelerin yapmış olduğu sadece yazılmış 2 tez olduğu görülmektedir. Tabloda yer alan diğer üniversitelerin bu alanda yazılmış doktora tezleri bulunmamaktadır.

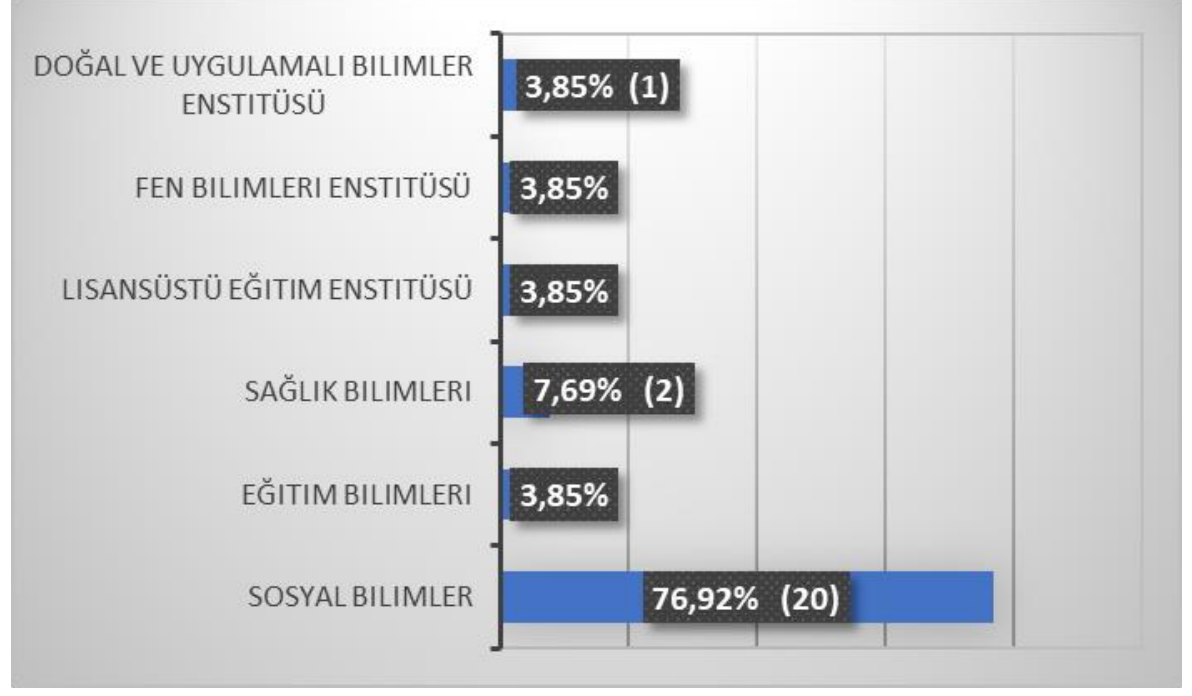

Şekil 1. Tezlerin Yayınladı̆̆g Enstitüler

Şekil 1'de, tezlerin yayınlanış oldukları enstitülere bakıldığında en fazla 20 çalışma ile \%76,92 orana sahip sosyal bilimler enstitüsündür. Sağlık bilimleri enstitüsü yapılan 2 çalışma ile \%7,69 orana sahipken en az çalışma yapılan enstitüler, 1 er çalışma ile eğitim bilimleri, fen bilimleri, uygulamalı bilimler ve lisansüstü eğitim enstitüsüdür. 


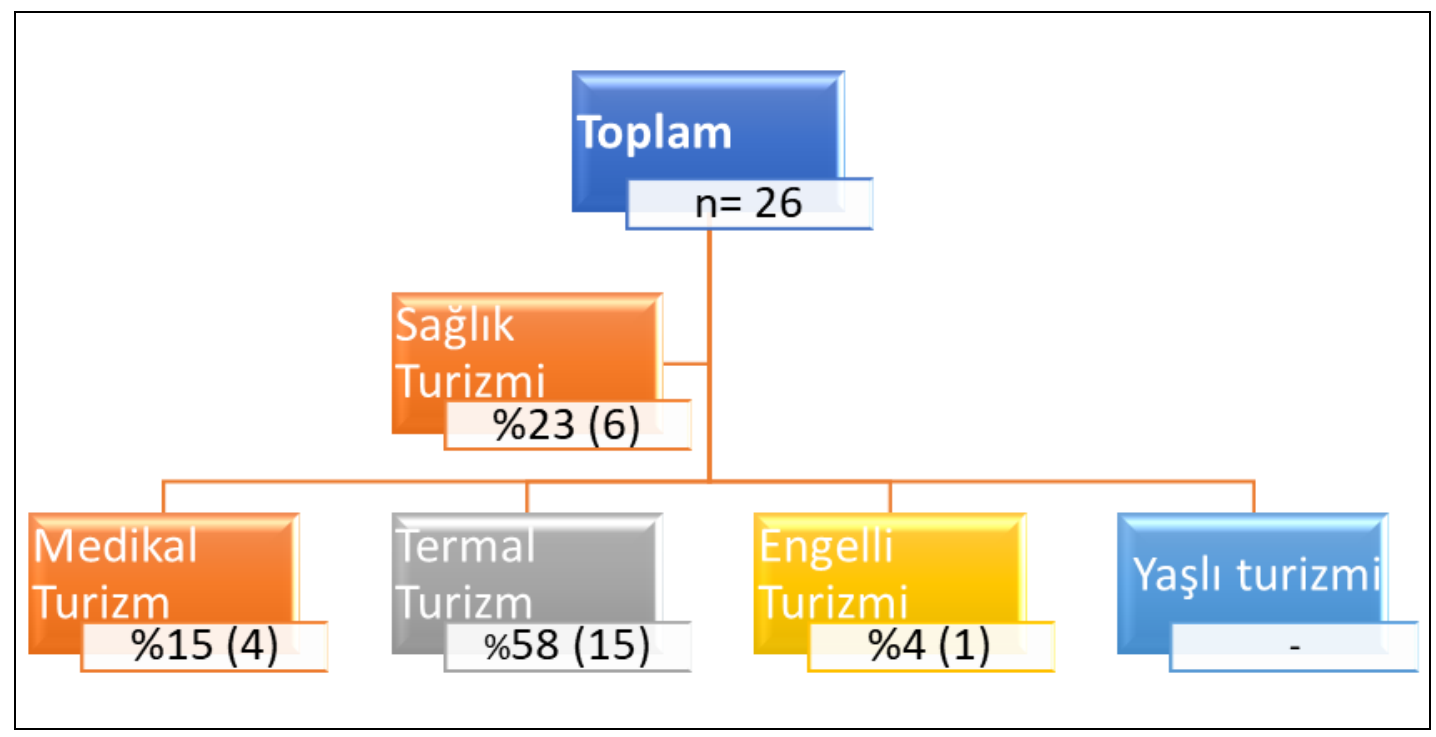

Şekil 2: Yapılan Tezlerin Temel Konu Alanlarına Göre Dağılımı

Yapılan Araştırma kapsamında tezlerin ele aldığı temel konu alanları incelendiğinde, tezlerin en fazla 15 çalışma ve \%58 oranla termal turizm alanında, 6 çalışma ve \%23 oranla sağlık turizmi alanında, 4 çalışma ve \%15 oranla medikal turizm alanında ve en az 1 çalışma ve \%4 oran ile engelli turizm alanlarında yapılmış çalışmalar olduğu görülmektedir. İç Anadolu Bölgesinde yaşlı turizmi ve ileri yaş turizmi konuları altında yapılmış olan çalışmalara rastlanmamıştır.

Tablo 6. Sağlık Turizmi Alanında Yayınlanan Tezlerin Konuları

\begin{tabular}{llc|}
\multicolumn{1}{c}{ Çalışılan Konular } & n & \% \\
\hline Müşteri memnuniyeti & 3 & 11.54 \\
\hline Regresyon faaliyetleri & 1 & 3.85 \\
\hline Bölgesel kalkınma & 1 & 3.85 \\
\hline Marka kent & 1 & 3.85 \\
\hline Örgütsel bağlılık & 1 & 3.85 \\
\hline Müşteri ilişkileri & 1 & 3.85 \\
\hline Seyahat motifi & 1 & 3.85 \\
\hline Kurumsal ve mekânsal boyutlar & 1 & 3.85 \\
\hline Turizm potansiyeli & 2 & 7.69 \\
\hline
\end{tabular}




\begin{tabular}{|lcc|}
\hline Jeotermal sular & 1 & 3.85 \\
\hline Alternatif turizm & 1 & 3.85 \\
\hline Turizm paydaşları & 1 & 3.85 \\
\hline Hizmet kalitesi & 3 & 11.54 \\
\hline Destinasyon sadakati & 1 & 3.85 \\
\hline Rekreatif Etkinlikler & 1 & 3.85 \\
\hline Ev pansiyonculuğu & 1 & 3.85 \\
\hline Kaplıca ve termal tesisler & 1 & 3.85 \\
\hline Medikal turizm & 1 & 3.85 \\
\hline Turizm potansiyeli & 1 & 3.85 \\
\hline Pazarlama çalışmaları & 1 & 3.85 \\
\hline Sosyal ağ kuramı & 1 & 3.85 \\
\hline Toplam & 26 & 100 \\
\hline
\end{tabular}

Tablo 6'da Sağlık Turizmi alanında, İç Anadolu Bölgesine yönelik yüksek lisans ve doktora tezlerinde hangi konuların ağırlıkta olduğuna bakılmıştır. Bu tabloya göre, müşteri memnuniyeti ve hizmet kalitesi 3'er kez çalışılmış olup bu konuların oranı ise genel oran içerisinde \%11.54'dür. Turizm potansiyeli $2 \mathrm{kez}$ çalışılmış olup \%7,69 orana sahiptir. Tabloda yer alan diğer konu başlıkları 1'er kez çalışılmış olup her biri \%3,85 orana sahiptir. 


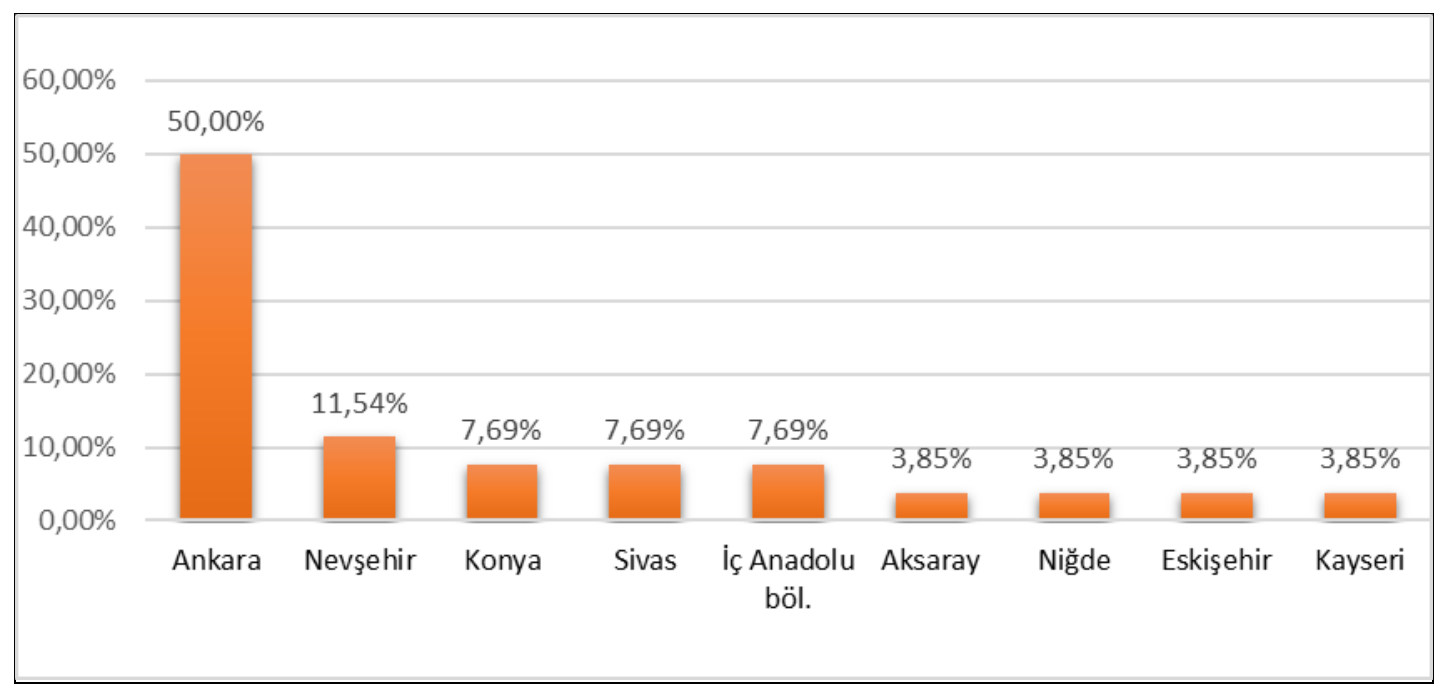

Şekil 3: Tezlerin İç Anadolu Bölgesinde Yer Alan Şehir Örneklemlerine Göre Dağılımı

Tezlerdeki araştırmaların yapıldığı şehir dağılımlarına bakıldığında, Ankara (\%50), Nevşehir (\%11.54) Konya ve Sivas $(\% 7,69)$, Aksaray, Niğde, Eskişehir, Kayseri illerine ise \%3,85 orana sahiptir. Genel anlamda İç Anadolu Bölgesine yönelik yapılan çalışma oranı ise \% 7,69'dur. Elde edilen bulgulara göre en çok çalışma alanının Ankara ili olduğu görülmektedir. İç Anadolu Bölgesinde toplam 13 il yer almaktadır. Tabloda ise çalışma yapılmış 8 il bulunmaktadır. İç Anadolu Bölgesinde yer alan diğer şehirlerde sağlık turizmi alanında yapıllmış çalışmalara rastlanmamıştır.

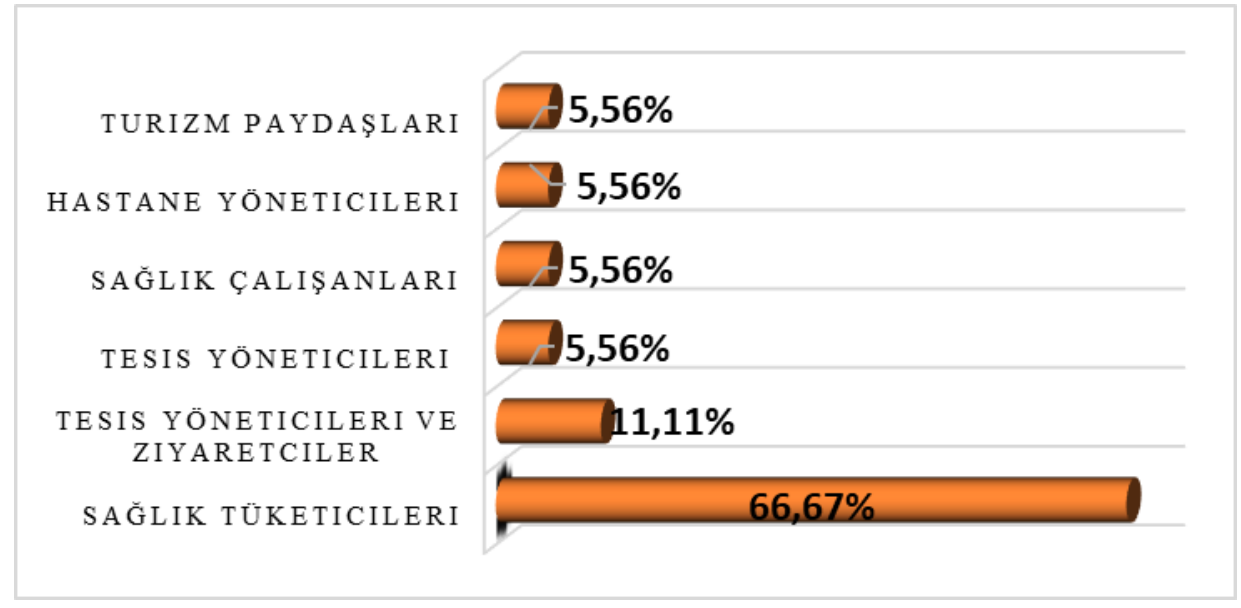

Şekil 4: Tezlerin Örneklem Gruplarının Dağılımı

Araştırma kapsamında toplam 18 anket çalınmasına rastlanılmıştır. Tezlerin örneklem gruplarına bakıldığında, tezlerin $12(\% 66,67)$ 'sinin sadece sağlık tüketicilerinin, $2(\% 11,11)$ 'sinin tesis 
yöneticilerinin ve sağlık tüketicilerinin oluşturduğu görülmektedir. Turizm paydaşları, hastane yöneticileri, sağlık çalışanları ve tesis yöneticilerin 1 er örneklem oluşturmuş olup \%5,56 orana sahiptir. En çok örneklem gurubunun sağlık tüketicilerinin oluşturduğu görülmektedir.

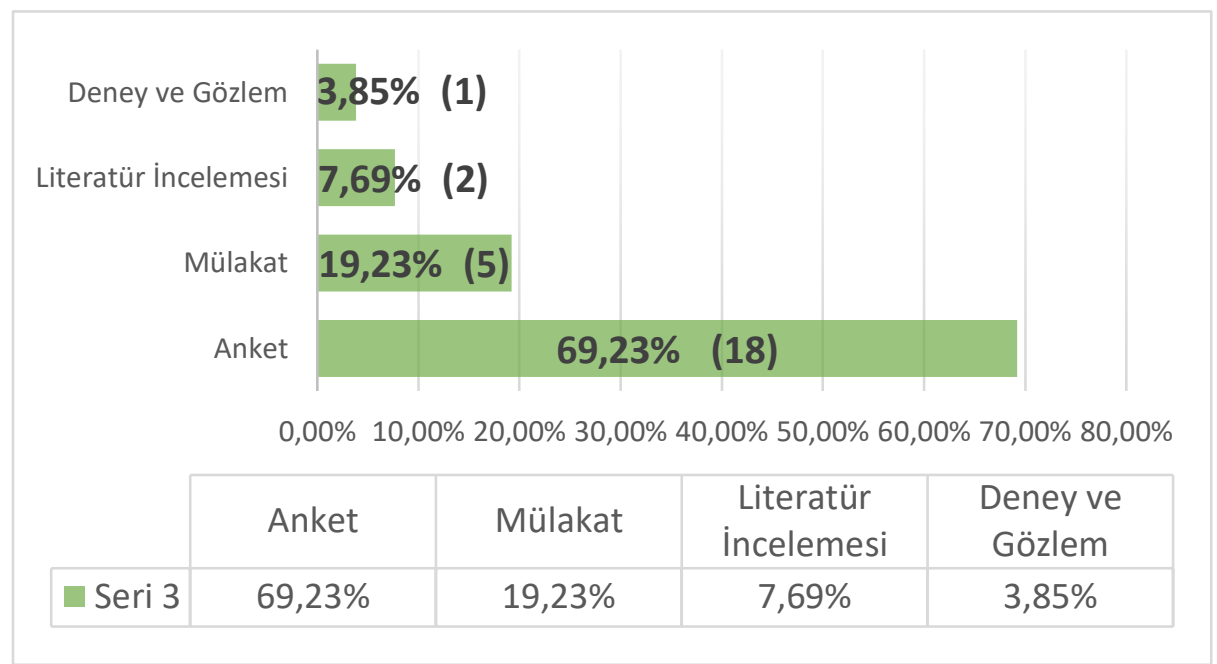

Şekil 5. Yazılan tezler de kullanılan veri toplama teknikleri

Sağlık turizmi alanında yayınlanan tezlerin veri toplama yöntemlerine bakıldığında, yapılan tezlerde $\% 69,24$ oranında anket yönteminin kullandığ1; \%19,23 oranında mülakat yönteminin kullandığı; \% 7,69 oranında ise literatür derlemesi şeklinde yazıldığı ve \%3,85 oranında çalışmanın da deney ve gözleme dayalı yapıldığı belirlenmiştir. Araştırma yöntemi olarak tezlerde en çok anket yönteminin kullanıldığı görülmektedir.

\section{Sonuç}

Sağlık turizmi alanında İç Anadolu Bölgesine yönelik yapılmış olan yüksek lisans ve doktora tezlerinin yıllara göre dağılımına bakıldığında, tezlerin neredeyse yarısının son beş sene içerisinde yayınlanmış olduğu tespit edilmiştir. Yine yapılmış oldukları anabilim dallarına bakıldığında ise en çok "Turizm İşletmeciliği" ve "İşletme" anabilim dallarında yapılmış oldukları görülmektedir. Yapılan Araştırma neticesinde yayınlanan tezlerin en çok sosyal bilimler alanında yapılmış olduğu görülmektedir. Bununla birlikte; sağlık, eğitim, fen ve uygulama bilimleri gibi çeşitli alanlarda da yapılmış çalışmalar olduğu görülmektedir. Farklı alanlarda yapılan bu çalışmalar sağlık turizminin 
multidisipliner bir alan olduğundan kaynaklanmaktadır. Çalışmalarda genellikle "müşteri memnuniyeti" ve "hizmet kalitesi" ele alınmış olup örneklem seçimini sağlık tüketicileri oluşturmaktadır. Çalışmalarda kullanılan veri toplama tekniği ise genellikle anket yöntemidir.

Tezlerin ele almış olduğu temel konu alanları incelendiğinde en çok çalışılan alanının sağlık turizminin içinde barındırdığı, termal turizm alanında yapılmış çalışmalar olduğu görülmektedir. Türkiye, coğrafi konumu, tarihi değerleri, doğal güzellikleri ve termal turizm açısından potansiyeli yüksek olan bir ülkedir. Termal turizmde araştırmaların en çok yapıldığı İç Anadolu Bölgesinde yer alan Ankara ili Kızılcahamam ilçesinin termal turizm açısından gelişmiş olduğu dikkat çekmektedir. Sağlık turizmi çatısı altında yer alan medikal turizm ve engelli turizmi açısından İç Anadolu Bölgesine yönelik yapılmış çalışma sayısı oldukça azdır. Yaşlı turizmi ve ileri yaş turizmi olarak hiç ele alınmamıştır. Diğer taraftan, İç Anadolu Bölgesinde yaşlı ve engelli turizmini barındıran "Bakım ve Rehabilitasyon Turizmi" ne ihtiyaç duyanlara yönelik çalışmaların yapılması da önerilmektedir.

$\mathrm{Bu}$ çalışma, sağlık turizmine genel bir bakış açısıyla bakabilmek amacıyla ve İç Anadolu Bölgesine yönelik sağlık turizmi alanında yapılmış olan tezler hakkında bir değerlendirmede bulunmak için yapılmıştır. Yapılan bu değerlendirme, sağlık turizmi alanında öğrencilere ve akademisyenlere çalışacakları konular yönünden yol göstereceği düşünülmektedir.

\section{Kaynakça}

Akat, Ö. (2000), Pazarlama Ağırlıklı Turizm İşletmeciliği, Motif Matbaa, 3. Basım, Bursa.

Akbulut, G. (2010). Türkiye'de Kaplıca Turizmi ve Sorunları. Gaziantep University Journal of Social Sciences, 9(1). https://dergipark.org.tr/en/download/article-file/223540 (E.T. 01.10.2021).

Asadi, R., \& Daryaei, M. (2011). Strategies for development of Iran health tourism. European Journal of Social Sciences, 23(3), 329-344. https://www.researchgate.net/publication/215897808 (E.T. 01.10.2021).

Aydın, D., \& Yılmaz, C. (2010). Temel Sağlık Hizmetleri Genel Müdürlüğü (Sağlık Turizmi Birimi) Medikal Turizm Araştırması (Birinci Bölüm) Ankara. Erişim adresi: 
https://docplayer.biz.tr/743109-T-c-saglik-bakanligi-temel-saglik-hizmetlerigenel\%20mudurlugu-saglik-turizmi-birimi.html (E.T. 15.05.2021).

Aydın, D., Şeker, S., \& Şahan, S. (2011). Kamu hastanelerinde sağlık turizmi ve turistin sağlığı uygulama rehberi. Sağlık Bakanlığ1, Ankara. https://hastane.gop.edu.tr/saglikturizmi/docs/2.pdf (E.T. 23.09.2021).

Aydın, O. (2012). Türkiye'de alternatif bir turizm; sağlık turizmi. Karamanoğlu Mehmetbey Üniversitesi Sosyal ve Ekonomik Araştırmalar Dergisi, 2012(2), 91-96. https://dergipark.org.tr/tr/download/article-file/107272 (E.T. 20.09.2021).

Balcı, Ş., \& Bekiroğlu, O. (2012). İçerikten anlama giden bir tünel olarak içerik çözümlemesi: 2011 genel seçimlerinde ak parti tv reklamları üzerine bir araştırma. İletişim Bilimlerinde Araştırma Yöntemleri Görsel Metin Çözümleme, Ütopya Yayınevi, Ankara.

Bookman, M. (2007). Medical tourism in developing countries. Springer.

Boz, M. (2019). Turizmin Gelişmesinde Alternatif Turizm Pazarlamasının Önemi: Antalya Örneği. Türk Turizm $\quad$ Araştırmaları $\quad$ Dergisi, 3 (4), 977-994. https://www.tutad.org/index.php/tutad/article/view/113 (E.T. 13.09.2021).

Connell, J. (2006). Medical tourism: Sea, sun, sand and... surgery. Tourism management, 27(6), 1093-1100.

Connell, J. (2013). Çağdaş medikal turizm: Kavramsallaştırma, kültür ve metalaştırma. Turizm işletmeciliği, 34, (1-13).

Dağıstan, H. (2013). Türkiye jeotermal kaynak aramaları, kullanımı ve sürdürülebilirliğinin sağlanması. MTA Doğal Kaynaklar ve Ekonomi Bülteni (15), 1-10. https://www.mta.gov.tr/v3.0/sayfalar/hizmetler/kutuphane/ekonomi bültenleri/2013_15/1.pdf (E.T. 20.09.2021).

Deniz, M. (2016). Türkiye Sağlık Turizmi ve Seçilmiş Ülkelerle Karşılaştırılması. Atılım Üniversitesi, Sağlık Kurumları İşletmeciliği, (Yüksek Lisans Tezi).

Doğanay, H., \& Zaman, S. (2001). Türkiye turizm coğrafyası (Vol. 3). Konya: Çizgi Kitabevi. Erfurt-Cooper, P. ve Cooper, M. (2009). Sağlık ve sağlık turizmi. Kanal Görüntüleme Yayınları. 
Fiske, J. (2014). İletişim Çalışmalarına Giriş (Çev. Süleyman İrvan). (3. Baskı). Ankara: Pharmakon Yayınevi. https:// www.docdroid.net/uwzx/john-fiske-iletisim-calismalarina-girispdf\#page=5 (E.T. 17.07.2021).

Gençay, C. (2007). Sağlık Turizmi, (Ed.) M. Bulu ve İH Eraslan, Sürdürülebilir Rekabet Avantaj1 Elde Etmede Turizm Sektörü, (ss. 172-180). İstanbul: Kazancı Hukuk Yayım evi.

Gökçe, O. (2006). İçerik analizi: Kuramsal ve pratik bilgiler. Siyasal kitabevi.

Güleç D. (2011) Sağlık Turizmi Kapsamında Antiaging (Sağlıklı Yaşlanma) Uygulamaları ve Yaşlı Bakımı: Türkiye Değerlendirmesi. Gazi Üniversitesi, Sosyal Bilimler Enstitüsü, Yüksek Lisans Tezi, Ankara

Hasanov, A. (2018). Sağlık Turizmi Kapsamındaki Medikal Turizmin Mevcut durumu, Potansiyeli ve Geleceği: Türkiye’nin Medikal Turizm Değerlendirmesi, İstanbul Aydın Üniversitesi, Sosyal Bilimler Enstitüsü, İşletme Anabilim Dalı, İşletme Yöneticiliği Programı, Yüksek Lisans Tezi. İstanbul

Horowitz, M. D., Rosensweig, J. A., \& Jones, C. A. (2007). Medical Tourism: Globalization of the Healthcare Marketplace. Medscape General Medicine, 9(4), 33. https://www.ncbi.nlm.nih.gov/pmc/articles/PMC2234298/(E.T. 19.08.2021).

İçöz O., (2009). Sağlık Turizmi Kapsamında Medikal (Tıbbi) Turizm ve Türkiye’nin Olanakları, Journal of Yaşar University, 4(14):2257-2279. https://dergipark.org.tr/en/download/articlefile/179233 (E.T. 13.08.2021).

İlban M. O., Köroğlu A., Bozok D., (2008). Termal Turizm Amaçlı Seyahat Eden Turistlerde Destinasyon İmajı: Gönen Örneği, İstanbul Ticaret Üniversitesi Sosyal Bilimler Dergisi, 13: 105129. http://ticaret.edu.tr/uploads/kutuphane/dergi/s13/105-129.pdf (E.T. 16.07.2021).

Karakoç, S. (2017). Küresel dünyada sağlık turizminin önemi ve Türkiye’nin durumu. Basılmamış Yüksek lisans Tezi). Kayseri: Erciyes Üniversitesi Turizm İşletmeciliği Ana Bilim Dalı.

Kaya S., Yıldırım H.H., Karsavuran S., Özer Ö., (2013). Türkiye Medikal Turizm Değerlendirme Raporu 2013, Türkiye Cumhuriyeti Sağlık Bakanlığı, Sağlık Hizmetleri Genel Müdürlüğü, Sağlık Turizmi Daire Başkanlığı. 
Koçak, A. \& Arun, Ö. (2013). İçerik Analizi Çalışmalarında Örneklem Sorunu. Selçuk İletişim, 4 (3), 21-28. https://dergipark.org.tr/en/download/article-file/177956 (E.T. 14.08.2021).

Lunt, N., Smith, R., Exworthy, M., Green, S. T., Horsfall, D., ve Mannion, R. (2011). Medical tourism: treatments, markets and health system implications: a scoping review. Özer, Ö., \& Sonğur, C. (2012). Türkiye'nin dünya sağlık turizmindeki yeri ve ekonomik boyutu. Mehmet Akif Ersoy Üniversitesi Sosyal Bilimler Enstitüsü Dergisi, 4(7), 69-81.

Özgül, A. (2014). Türkiye'de sağlık politikaları üzerine bir değerlendirme. Yayınlanmamış yüksek lisans tezi. Süleyman Demirel Üniversitesi, Sosyal Bilimler Enstitüsü. Isparta.

Özsarı, S. H., \& Karatana, Ö. (2013). Sağlık turizmi açısından Türkiye'nin durumu. Journal of Kartal Training \& Research Hospital/Kartal Eğitim ve Araştırma Hastanesi Tip Dergisi, 24(2). doi: $10.5505 /$ jkartaltr.2013.69335

Öztürk, M., \& Bayat, M. (2011). Uluslararası turizm hareketlerinde sağlık turizminin rolü ve kalite çalışmalarının önemi bir literatür çalışması. Kahramanmaraş Sütçü İmam Üniversitesi İktisadi ve İdari Bilimler Fakültesi Dergisi, 1(2), 135-156.

Pollard, K. (2010). Medical tourism statistics: Comparing apples with apples. IMTJ, London: https://www.imtj.com/articles/medical-tourism-statistics-comparing-apples-apples/

(E.T. 20.10.2020).

Reisman, D. A. (2010). Health tourism: Social welfare through international trade. Edward Elgar Publishing.

Tengilimoğlu, D., Yalçın Balçık, P. (2009). What Should Turkey's Marketing Strategy Be in Health Tourism. In Proceedings of the Annual Meeting of the Association of Collegiate Marketing Educators (66-81).

Türksoy, A., \& Türksoy, S. S. (2010). Termal Turizmin Geliştirilmesi Kapsamında Çeşme İlçesi Termal Kaynaklarının Değerlendirilmesi. Ege Academic Review, 10(2), 699-725

Ülker, İ. (1994). Sağlık Turizmi Kavramlar, Planlama, Tanıtım. Ankara: Turizm Bakanlığı Yayınları.

http://treatmentabroad.blogspot.com/2010/03/medical-tourism-statistics-comaaring.html (E. T. 08.12.2020). 
İ̧̧ Anadolu Bölgesine Yönelik Sağlık Turizmi Alanında 2006-2020 Yılları Arası Yapılmış Tez̆lerin İçerik Analizi

https://www.yumpu.com/tr/document/read/25951616/saglik-turizmi-ve-turistin-sagligi-saglkbakanlg (E. T. 10.12.2020).

https://antalya.ktb.gov.tr/TR-68438/saglik-turizmi.html (E. T. 08.12.2020)

YÖK Tez Veri Tabanı, https://tez.yok.gov.tr/UlusalTezMerkezi/ (E.T. 05.12.2020). 